\title{
PARTISIPASI MASYARAKAT DALAM PENGELOLAAN SAMPAH (Studi Deskriptif Kec. Curup Tengah, Kab. Rejang Lebong, Bengkulu)
}

\author{
COMMUNITY PARTICIPATION IN GARBAGE MANAGEMENT \\ ( Descriptive Study District of Curup Central, Rejang Lebong, Bengkulu )
}

\author{
Bayu Panji Aji \\ Pemda Kabupaten Rejang Lebong \\ Jl. A.Yani No.5 Kelurahan Kesambe Baru Kec. Curup Timur Kab.Rejang Lebong \\ Email : bayupanjiaji@gmail.com
}

\begin{abstract}
ABSTRAK
Semakin meningkatnya laju pertumbuhan penduduk, ekonomi dan pembangunan yang terjadi di Kecamatan Curup Tengah, Kabupaten Rejang Lebong, Bengkulu telah menyebabkan semakin meningkatnya timbulan sampah yang dihasilkan. Hal ini dapat menyebabkan menurunnya kualitas lingkungan di wilayah tersebut, apalagi keadaan ini semakin diperparah akibat kurang memadainya penanganan dan sistem pengelolaan sampah yang dilaksanakan oleh pihak Pemerintah Daerah. Oleh karena itu, diperlukan upaya nyata dalam menyelesaikan permasalahan sampah yang ada seperti dengan meningkatkan partisipasi masyarakat dalam pengelolaan sampah.

Penelitian ini bertujuan untuk mengetahui bagaimana partisipasi masyarakat dalam pengelolaan sampah di Kecamatan Curup Tengah. Partisipasi ini dapat berbentuk pasrtisipasi masyarakat dalam penentuan kebijakan Pemerintah daerah tentang pengelolaan sampah. Bentuk pasrtisipasi masyarakat yang lain dapat dilihat dengan membuang sampah pada tempat yang telah disediakan, tidak membuang sampah di tempat pembuangan terbuka, serta dengan tidak membakar sampah yang tidak sesuai dengan teknis persyaratan pengelolaan sampah.

Hasil analisa menunjukkan bahwa Partisipasi masyarakat dalam penentuan kebijakan Pemerintah Daerah tentang Pengelolaan sampah di Kec. Curup Tengah, Kab. Rejang Lebong, Bengkulu sudah baik dengan nilai rata-rata jawaban responden terhadap kuisioner adalah 3,83, Partisipasi masyarakat dengan membuang sampah pada tempat yang telah ditentukan atau disediakan di Kec. Curup Tengah, Kab. Rejang Lebong, Bengkulu sudah baik dengan nilai rata-rata jawaban responden terhadap kuisioner adalah 3,91, Partisipasi masyarakat dengan tidak membuang sampah di lapangan terbuka di Kec. Curup Tengah, Kab. Rejang Lebong, Bengkulu sudah baik dengan nilai rata-rata jawaban responden terhadap kuisioner adalah 3,77, dan Partisipasi masyarakat dengan tidak membakar sampah yang tidak sesuai dengan persyaratan teknis pengelolaan sampah di Kec. Curup Tengah, Kab. Rejang Lebong, Bengkulu sudah baik dengan nilai rata-rata jawaban responden terhadap kuisioner adalah 3,69. Hal ini menunjukkan bahwa secara umum Partisipasi masyarakat Dalam Pengelolaan Sampah di Kecamatan Curup Tengah, Kabupaten Rejang Lebong, Bengkulu sudah baik dengan nilai rata-rata nilai jawaban responden adalah 3,8 .
\end{abstract}

Kata Kunci : partisipasi, masyarakat, sampah 


\section{ABSTRACT}

The increasing rate of population growth and economic development occurring in the Curup Tengah District, Kab. Rejang Lebong, Bengkulu has led to the increasing waste generated. This can lead to declining environmental quality in the region, especially the situation is aggravated by inadequate handling and waste management systems are implemented by the Regional Government. Therefore, the required real effort in resolving the existing problems of waste such as by increasing community participation in waste management.

This study aims to determine how community participation in waste management in the Curup Tengah District. This participation may take the form pasrtisipasi community in local government policy decisions about waste management. Pasrtisipasi other forms of society can be seen by taking out the trash in the space provided, do not throw garbage in open dumps, as well as by not burning waste not in accordance with the technical requirements for waste management.

Results of analysis showed that public participation in policy-local government on waste management in the Curup Tengah District, Kab. Rejang Lebong, Bengkulu was well with the average value of respondents' answers to the questionnaire was 3.83, Participation of the community by removing trash in places that have been prescribed or provided in the Curup Tengah District, Kab. Rejang Lebong, Bengkulu was well with the average value of respondents' answers to the questionnaire was 3.91, with community participation does not throw garbage in the open field in the Curup Tengah District, Kab. Rejang Lebong, Bengkulu was well with the average value of respondents' answers to the questionnaire is 3.77 , and the participation of the community by not burning waste not in accordance with technical requirements for waste management in the Curup Tengah District, Kab. Rejang Lebong, Bengkulu was well with the average value of respondents' answers to the questionnaire was 3.69. This shows that the general public's Participation in the Waste Management at Curup Tengah District, Kab. Rejang Lebong, Bengkulu was well with the average value of the respondent's answer was 3.8.

Keywords: participation, community, garbage

\section{PENDAHULUAN}

Semakin meningkatnya laju pertumbuhan penduduk, ekonomi dan pembangunan suatu kota, maka timbulan sampah juga akan meningkat. Hal ini dapat menyebabkan menurunnya kualitas lingkungan perkotaan karena pengelolaan persampahan yang kurang memadai. Oleh karena itu, perlu dilaksanakan suatu cara untuk menangani masalah sampah tersebut sehingga fenomena sampah yang selama ini terjadi pada kota tidak menjadi masalah serius bagi warga masyarakat perkotaan maupun masyarakat pedesaan. Masalah persampahan ini telah mengakibatkan pencemaran lingkungan secara berantai, seperti bau busuk yang mengganggu, sumber penularan penyakit serta tersumbatnya drainase dan sungai yang dapat mengakibatkan banjir.

Melihat kondisi tersebut, penanganan sistem pengelolaan persampahan suatu kota harus dilaksanakan dengan efisien dan efektif, sehingga dapat dicapai hasil maksimal sesuai yang diharapkan oleh masyarakat dan pemerintah. 
Perkembangan permukiman yang diiringi dengan semakin padatnya penduduk menyebabkan semakin sulitnya pengelolaan sampah secara mandiri, disamping itu meningkatnya aktifitas yang ada tentunya membutuhkan suatu lingkungan yang bersih dan sehat.

Pengelolaan sampah sesungguhnya merupakan tugas dan tanggung jawab bersama antara pemerintah sebagai penyedia dan masyarakat yang membutuhkan. Pengelolaan sampah secara efektif dan efisien harus dijalankan oleh semua pihak, baik masyarakat maupun pemerintah. Permasalahan sampah merupakan hal yang krusial bahkan sampah dapat dikatakan sebagai masalah kultural karena dampaknya terkena pada berbagai sisi kehidupan.

Peningkatan volume sampah berkembang secara eksponensial yang belum dibarengi dengan peningkatan pendapatan Pemerintah Daerah yang sepadan untuk pengelolaan sampah kota. Sehingga permasalahan sampah kurang menjadi prioritas Pemerintah Daerah. Hal ini semakin membuat membuat permasalahan sampah akan semakin kompleks dan akan membutuhkan biaya yang tinggi dalam penanggulangannya. Suatu studi tentang keadaan pemukiman di Jakarta menunjukkan bahwa $30 \%$ dari sampah sehari-hari dibuang ke kali dan menyumbat selokan (Taylor \& Williams, 1982).

Kecamatan Curup tengah, merupakan salah satu Kecamatan di wilayah Kabupaten Rejang Lebong, dimana jumlah penduduknya semakin meningkat tiap tahunnya. Peningkatan jumlah penduduk ini pasti akan semakin meningkatkan volume sampah yang dihasilkan oleh penduduk yang ada di wilayah Kecamatan Curup Tengah tersebut. Menghadapi peningkatan jumlah volume sampah tersebut Pemerintah Kabupaten Rejang Lebong telah melakukan upaya pengawasan dan penyelematan melalui kelembagaan yang ada yakni melalui Badan Lingkungan Hidup, Kebersihan Dan Pertamanan (BLHKP) Kabupaten Rejang Lebong. Lembaga ini dimaksudkan untuk mencegah dan mengantisipasi kerusakan lingkungan hidup atau memulihkan kerusakan yang terjadi, minimal untuk menurunkan derajat kerusakan lingkungan hidup yang ada di Kabupaten Rejang Lebong.

Dalam pengelolaan sampah yang ada di Kabupaten Rejang Lebong sangat diperlukan keikutsertaan masyarakat. Peran serta masyarakat ini perlu menjadi perhatian serius karena untuk menghindari kecenderungan partisipasi semu dari masyarakat. Sehingga nantinya diharapkan masyarakat dapat mengerti 
dan memahami tentang apa dan untuk apa mereka harus melakukan suatu kegiatan pembangunan atau lebih spesifik lagi dalam pengelolaan sampah.

Tata cara partisipasi masyarakat dalam pengelolaan sampah dapat dilakukan dengan memperhatikan karakteristik dan tatanan sosial budaya daerah masingmasing. Akan tetapi hal yang mendasar dari semuanya yaitu segala bentuk partisipasi masyarakat dalam pengelolaan sampah harus dilaksanakan dan dimulai dari kesadaran diri sendiri setiap individu masyarakat. Sehingga dapat dikatakan dengan kesadaran yang tinggi tentang pengelolaan sampah, maka akan menjadi sangat bermanfaat, baik itu bagi diri sendiri maupun orang lain disekitar kita serta lingkungan tempat kita tinggal.

\section{METODE PENELITIAN}

Penelitian ini dirancang sebagai penelitian kualitatif dengan pemaparan data secara deskriptif kualitatif. Penelitian ini meneliti subjek penelitian secara ilmiah. Proses dari penelitian ini adalah partisipasi masyarakat dalam pengelolaan sampah di Kecamatan Curup Tengah, Kabupaten Rejang Lebong, Bengkulu.

Penetapan lokasi penelitian di daerah ini dengan pertimbangan karena daerah ini merupakan kecamatan di Kabupaten Rejang Lebong dengan jumlah penduduk terbanyak yaitu 35.563 Jiwa (Badan Pusat
Statistik Kab. Rejang Lebong 2010).

Dengan kondisi tersebut membuat timbulan sampah yang dihasilkan masyarakat di wilayah kecamatan ini lebih banyak dibandingkan dengan masyarakat yang ada di Kecamatan lainnya. Sehingga perlu diketahui partisipasi nyata masyarakat di Kecamatan Curup Tengah dalam pengelolaan sampah untuk mencegah dan mengatasi permasalahan sampah di wilayah tersebut.

Penelitian ini menggunakan metode survey. Populasi dalam penelitian ini adalah seluruh masyarakat Kecamatan Curup Tengah yang berjumlah 35.563 Jiwa (BPS Kab. Rejang Lebong 2010).

\section{Sampel Penelitian}

Penentuan jumlah sampel penelitian diambil berdasarkan jumlah populasi yang adi di Kecamatan Curup Tengah Kabupaten Rejang Lebong yaitu 35.563 Jiwa. Pengambilan sampel ini menggunakan teknik persamaan Taro Yamane dalam Sudrajat (2001) dengan persamaan sebagai berikut :

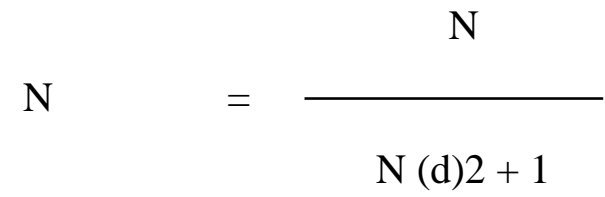

Keterangan :

$n=$ Jumlah Sampel

$\mathrm{N}=$ Jumlah Populasi

$\mathrm{d}=$ Tingkat presisi $(0,1)$ 
Berdasarkan persamaan tersebut, diperoleh sampel sebagai berikut :

$$
n=\frac{35.563}{35.563(0,1)^{2}+1}=99,7
$$

Berdasarkan perhitungan dalam mendapatkan jumlah sampel tersebut, maka diperoleh jumlah sampel sebanyak 99,7 orang atau dibulatkan menjadi 100 orang. Setelah jumlah sampel tersebut ditetapkan, maka selanjutnya menentukan sampel desa/kelurahan. Berdasarkan pertimbangan untuk mengetahui mengenai pengelolaan sampah secara menyeluruh, maka peneliti menetapkan mengambil sampel diseluruh kelurahan/desa yang ada di Kecamatan Curup Tengah yaitu Kelurahan Air Bang, Kelurahan Batu Galing, Kelurahan Banyumas, Kelurahan Siderejo, Kelurahan Kampung Jawa, Kelurahan Pelabuhan Baru, Kelurahan Kepala Siring, Kelurahan Talang Rimbo Baru, Kelurahan Talang Rimbo Lama, dan Desa Air Merah. Masing-masing kelurahan/desa ditarik sampel 10 (sepuluh) responden dengan teknik random sampling.

\section{HASIL DAN PEMBAHASAN}

Gambaran Pengelolaan Sampah Di Kota Curup

Berdasarkan data yang diperoleh peneliti dari Badan Lingkungan Hidup, Kebersihan dan pertamanan Kabupaten
Rejang Lebong, timbulan sampah yang dihasilkan di daerah yang terjangkau oleh pelayanan kebersihan yaitu sebanyak $2.815 \mathrm{~m}^{3} /$ bulan dengan jumlah sampah terangkut sekitar 2693, $75 \mathrm{~m}^{3} /$ bulan sehingga masih ada sisa sampah yang belum terangkut yaitu sebesar 121, 25 $\mathrm{m}^{3} /$ bulan. Sistem pengolahan sampah yang digunakan adalah landfill, dimana telah tersedia system $3 \mathrm{R}$ dengan kemampuan kapasitas pengolahan sampah untuk kegiatan Reduse sebesar $1 \mathrm{~m}^{3} /$ ton, Reuse sebesar $5 \mathrm{~m}^{3} /$ ton dan Recycle sebesar $104 \mathrm{~m}^{3} /$ bulan.

Teknologi pengomposan yang dilakukan Badan Lingkungan Hidup, Kebersihan dan pertamanan Kabupaten Rejang Lebong, dilakukan dengan 2 (dua) cara yaitu secara manual yang mengolah sampah sebesar $500 \mathrm{~m}^{3} /$ bulan sampai dengan 1 ton/bulan serta dengan menggunakan mesin pencacah yang mengolah sampah sebesar $104 \mathrm{~m}^{3} /$ bulan. Badan Lingkungan Hidup, Kebersihan dan pertamanan Kabupaten Rejang Lebong juga telah memiliki teknologi pembuatan kertas daur ulang dalam pengolahan sampah. Dari kegiatan pengolahan sampah tersebut sisa sampah yang belum terolah di kumpulkan di TPA yaitu di TPA Jambu Keling dan TPA Guru Agung di Kecamatan Padang Ulak Tanding (PUT). 
Dalam pelaksanaan untuk pemilahan sampah di Kota Curup. Petugas dari Badan Lingkungan Hidup, Kebersihan dan Pertamanan (BLHKP) Kabupaten Rejang Lebong dibantu oleh petugas $3 \mathrm{R}$ yang ada di sekolah-sekolah serta kelompok masyarakat seperti LSM peduli lingkungan yang bekerjasama dengan masyarakat yang ada di Kabupaten Rejang Lebong.

Kondisi Sistem Pengelolaan Sampah Bersadasarkan Pewadahan dan Pengangkutan di Kota Curup
Dalam data yang diperoleh peneliti dari Badan Lingkungan Hidup, Kebersihan dan pertamanan (BLHKP) Kabupaten Rejang Lebong dapat diketahui kondisi pewadahan dan pengangkutan dalam pengelolaan sampah yang ada di Kabupaten Rejang Lebong, secara rinci dapat dilihat dari tabel 1 .

Sedangkan kondisi sistem pewadahan sampah berdasarkan jenis penggunaan lahan dalam Kabupaten Rejang Lebong dapat dilihat dari tabel 2.

Tabel 1 Data Kondisi Sistem Pewadahan Dan Pengangkutan Sampah

\begin{tabular}{clcl}
\hline No & \multicolumn{1}{c}{ Jenis } & Jumlah & \multicolumn{1}{c}{ Kondisi } \\
\hline 1 & Gerobak Tanpa Roda & 150 Buah & Semua berfungsi \\
2 & TPS & 450 Buah & Semua berfungsi \\
3 & TPSS & 450 Buah & Semua berfungsi \\
4 & Dump Truck & 9 Unit & 4 Unit berfungsi, 5 Unit rusak \\
5 & Arm Roll Truck & 2 Unit & 1 Unit berfungsi, 1 Unit rusak \\
6 & Mobil L-300 & 2 Unit & Semua berfungsi \\
7 & Carry Compos & 2 Unit & 1 Unit berfungsi, 1 Unit rusak \\
8 & Bak Kontainer & 5 Unit & Semua berfungsi \\
9 & Alat Penglolaan Sampah & 2 Paket & 1 Paket di IPLT Tasik Malaya, 1 \\
& Terpadu 3 R & & Paket di Air Putih Baru
\end{tabular}

Sumber: BHKP Kabupaten Rejang Lebong, 2011 
Tabel 2 Kondisi Sistem Pewadahan Berdasarkan Jenis Penggunaan Sampah

\begin{tabular}{llccccc}
\hline & & & \multicolumn{3}{c}{ Kondisi Penggunaan Wadah } \\
NO & Jenis Wadah & Pemukiman & Pasar & $\begin{array}{c}\text { Tempat } \\
\text { Umum }\end{array}$ & $\begin{array}{c}\text { Pertokoan/ } \\
\text { Perkantoran }\end{array}$ & Jalan \\
& & $50 \%$ & $60 \%$ & $30 \%$ & - & $5 \%$ \\
\hline 1 & TPS & $10 \%$ & - & $20 \%$ & $30 \%$ & $20 \%$ \\
2 & Gerobak Roda 2 & $10 \%$ & $10 \%$ & $30 \%$ & $40 \%$ & $60 \%$ \\
3 & Tong Sampah & $10 \%$ & $10 \%$ & $10 \%$ & $20 \%$ & $15 \%$ \\
4 & TPSS & $20 \%$ & $20 \%$ & $10 \%$ & $10 \%$ & - \\
5 & Bak Kontainer & $\mathbf{1 0 0 \%}$ & $\mathbf{1 0 0 \%}$ & $\mathbf{1 0 0 \%}$ & $\mathbf{1 0 0 \%}$ & $\mathbf{1 0 0 \%}$ \\
\hline & TOTAL & &
\end{tabular}

Sumber: BHKP Kabupaten Rejang Lebong, 2011

Kegiatan 3R Badan Lingkungan Hidup, Kebersihan dan Pertamanan Kabupaten Rejang Lebong

Kegiatan 3R di Kabupaten Rejang Lebong setiap tahunnya dilaksanakan dengan menggunakan dana APBD Kabupaten Rejang Lebong, dimana untuk operasional dan pemeliharaan, biaya yang dihabiskan yaitu sebesar Rp. 23.000.000 pertahunnya. Unit 3R yang ada dilakukan secara manual dan diperuntukkan bagi sampah rumah tangga serta sayuran dari gudang penampungan. Proses 3R meliputi beberapa proses yaitu pemilahan, pencacahan dan pengomposan, proses pencacahan dan pengomposan dilaksanakan di IPLT Tasik Malaya dan telah dioperasikan untuk mengolah sampah sebesar $104 \mathrm{~m}^{3} / \mathrm{bulan}$.

Proses pemilihan sampah dilakukan oleh Petugas 3R yang ada disekolah-sekolah dan kelompok masyarakat serta juga ada yang dilakukan oleh para pemulung. Untuk proses pengelolaan dilakukan di beberapa titik seperti di Kesambe Lama, TPA Jambu Keling, dan Perumnas Batu Galing. Proses pengelolaan yang dilakukan dengan proses pengelolaan Open Dumping. Pada proses 3R ini juga menghasilkan residu, dimana residu yang tidak dapat di daur ulang tersebut dibuang di TPA Jambu Keling dan TPA Guru Agung Kec. Padang Ulak Tanding.

Konstruksi hanggar utama untuk unit proses 3R merupakan bangunan dengan besar kontruksi bangunan $2.000 \mathrm{~m}^{3}$ yang terdapat di area seluas $8.000 \mathrm{~m}^{2}$. Unit-unit yang ada yaitu unit penerimaan sampah, shredder (pemotong), bengkel dan gudang, alat penyaring kompos dan fasilitas umum lainnya. Suplai air untuk proses $3 \mathrm{R}$ didapat dari sumur galian dan juga menggunakan air dari sungai di sekitar area hangar utama. 
Dengan kondisi tersebut, BLHKP Kabupaten Rejang Lebong memasang target pencapaian pengelolaan volume sampah dengan program 3R yaitu pada tahun 2007 sekitar $40 \%$, Tahun 2009 sekitar $80 \%$, Tahun 2015 sekitar $90 \%$ dan tahun 2020 diharapkan dapat mencapai $95 \%$ dari volume sampah yang dihasilkan.

\section{Partisipasi Masyarakat dalam}

Penentuan Kebijakan oleh Pemerintah

Daerah tentang Pengelolaan Sampah Di

\section{Kecamatan Curup Tengah}

Partisipasi masyarakat dalam penetuan kebijakan oleh Pemerintah Daerah tentang pengelolaan sampah di Kecamatan Curup Tengah secara umum sudah baik. Hal ini dapat dilihat dari keaktifan masyarakat dalam memberikan usulan, pendapat maupun gagasan sebagai bahan masukkan bagi Pemerintah Daerah dalam menentukan setiap kebijakan tentang pengelolaan sampah yang disampaikan baik pada setiap kegiatan yang dilaksanakan oleh Pemerintah Daerah.

Penyampaian usulan dan pendapat merupakan salah satu tahapan dalam penentuan kebijakan publik yang berguna bagi masyarakat, selain itu juga merupakan sarana penyampaian aspirasi untuk menciptakan kesejahteraan masyarakat. Hal ini sesuai dengan pernyataan Dunn, William N. (1998) yang menyatakan Kebijakan publik adalah kebijakan-kebijakan yang dibuat oleh pemerintah sebagai pembuat kebijakan untuk mencapai tujuan-tujuan tertentu di masyarakat di mana dalam penyusunannya melalui berbagai tahapan. Dapat diketahui bahwa masyarakat di Kecamatan Curup Tengah sudah baik dalam mematuhi setiap kebijakan Pemerintah Daerah tentang pengelolaan sampah karena masyarakat beranggapan kebijakan yang dihasilkan tersebut merupakan bentuk kebijakan yang baik dan formal, sehingga dapat menciptakan keadaan yang baik dan tata nilai baru yang merubah kebiasaan masyarakat ke arah yang lebih baik dan lebih sejahtera. Hal ini sesuai dengan pendapat Dunn, William N. (1999) yang menyatakan bahwa Kebijakan adalah aturan tertulis yang merupakan keputusan formal organisasi, yang bersifat mengikat, yang mengatur perilaku dengan tujuan untuk menciptakan tata nilai baru dalam masyarakat.

Selain itu dari pernyataan yang disampaikan dapat diketahui pula bahwa perlu tingkat pendidikan dan pengalaman dalam memberikan saran, usulan, dan pendapat kepada Pemerintah Daerah tentang kebijakan pengelolaan sampah. Hal ini berkaitan dengan pandangan hidup, sikap hidup dan keterampilan hidup seseorang, karena makin tinggi 
pendidikan maka makin baik pandangan hidup, sikap hidup dan keterampilan hidup seseorang terhadap suatu persoalan atau permasalahan yang dihadapi. Sehingga dapat dengan jelas dilihat dengan pandangan, sikap hidup dan keterampilan hidup yang baik, seseorang akan mampu untuk mengerti dan mempertanggung jawabkan apa yang disampaikannya dalam memberikan saran, usulan dan pendapat dalam penentuan kebijakan yang berkaitan dengan kesejahteraan masyarakat termasuk dirinya sendiri. Hal ini juga sesuai dengan pernyataan Zamroni (2000) yang menyatakan bahwa pendidikan adalah proses yang berkaitan dengan upaya untuk mengembangkan diri seseorang yang terdiri dari tiga aspek kehidupan, yakni pandangan hidup, sikap hidup, dan keterampilan hidup. Dimana upaya untuk mengembangkan ketiga aspek tersebut dapat dilaksanakan baik disekolah, luar sekolah maupun keluarga.

Menurut Timney (1998) bahwa ketika masyarakat dan pemerintah bekerja sama dan berbagi dalam pembuatan kebijakan disebutnya sebagai pemerintahan dengan masyarakat (government with the people). Hal tersebut sangat berguna bagi penguatan kapasitas terhadap masyarakat sehingga pada akhirnya masyarakat dapat terberdaya serta mampu dan mau untuk berpartisipasi secara aktif dan efektif.
Namun diperlukan rasa saling percaya antara Pemerintah Daerah dengan warga masyarakat guna meningkatkan keterlibatan masyarakat dalam penyelenggaraan Administrasi Publik itu sendiri.

Berdasarkan teori dan dibandingkan dengan hasil penelitian yang telah dilakukan, bahwa nilai rata-rata jawaban responden terhadap kuisioner dan hasil wawancara yang dilakukan penelitian selama penelitian berlangsung, pernyataan dari responden bahwa partisipasi masyarakat dalam penentuan kebijakan Pemerintah Daerah tentang pengelolaan sampah di Kecamatan Curup Tengah, Kabupaten Rejang Lebong secara umum sudah baik dengan rata-rata nilai atas jawaban responden adalah 3,83. Masyarakat telah berpartisipasi aktif dengan selalu memberikan saran, usulan dan pendapat kepada Pemerintah Daerah yang dapat dijadikan sebagai bahan masukkan atau pertimbangan Pemerintah Daerah agar dapat menciptakan kebijakan pengelolaan sampah yang baik demi mensejahterakan kehidupan masyarakat

\section{Partisipasi Masyarakat dalam} Membuang Sampah di Tempat yang Telah Ditentukan atau Disediakan di Kecamatan Curup Tengah

Partisipasi masyarakat dalam membuang sampah pada tempat yang telah ditentukan 
atau disediakan di Kecamatan Curup tengah secara umum sudah baik. Hal ini dapat dilihat dari kesadaran masyarakat dalam mengelola sampah yang ada di lingkungannya sendiri dengan selalu menyediakan bak atau wadah tempat sampah di lingkungan dan rumah tempat mereka tinggal. Namun hal yang paling penting adalah bagaimana kesadaran masyarakat untuk selalu membiasakan diri dalam menggunakan bak sampah sebagai sarana untuk membuang sampah yang mereka hasilkan sehari-hari dimanapun mereka berada.

Menurut Andang Binawan (2010) kebiasaan membuang sampah sembarangan dilakukan hampir di semua kalangan masyarakat, tidak hanya warga miskin, bahkan mereka yang berpendidikan tinggi pun melakukannya. Ini sangat menyedihkan karena minimnya pengetahuan tentang sampah dan dampaknya. Perilaku buruk ini semakin menjadi karena minimnya sarana kebersihan yang mudah dijangkau oleh masyarakat di tempat umum.

Atas dasar teori diatas, kebiasaan diri untuk membuang sampah pada tempatnya sangat diperlukan karena akan mampu secara nyata mengurangi dampak-dampak yang dihasilkan dari permasalahan sampah yang terjadi di lingkungan kita. Selain itu dapat juga dilihat bahwa sesungguhnya faktor pendidikan yang tinggi juga bukan merupakan jaminan bahwa seseorang akan memiliki kebiasaan dan kesadaran diri yang baik dalam berperilaku sehari-hari terhadap pengelolaan sampah di lingkungannya.

Menurut Thobanoglous (1993), sistem pewadahan harus memperhatikan jenis sarana pewadahan yang digunakan, lokasi penempatan sarana pewadahan, keindahan dan kesehatan lingkungan. Persyaratan sarana pewadahan adalah tidak mudah rusak dan kedap air kecuali kantong plastik atau kertas, mudah diperbaiki, ekonomis/mudah diperoleh atau dibuat oleh masyarakat, serta mudah dan cepat dikosongkan.

Dapat diketahui bahwa seharusnya bak atau wadah tempat membuang sampah yang disediakan harus tidak mudah rusak, mudah diperbaiki atau ekonomis. Hal ini dikarenakan wadah atau bak sampah dianggap hal yang penting dalam pengelolaan sampah di masyarakat dan merupakan sarana utama untuk mengumpulkan sampah yang dihasilkan masyarakat sehari-hari. Sehingga sebagai salah satu bentuk partisipasi mengelola sampah di daerah atau lingkungannya, bila terjadi kerusakan terhadap wadah atau bak sampah yang ada di lingkungan seharusnya masyarakat dengan segera untuk diperbaiki atau diganti demi tetap terjaganya kebersihan lingkungan. 
Saling bekerja sama dalam masyarakat untuk menyediakan sarana dan prasarana pengelolaan sampah seperti Tempat Pembuangan Sementara (TPS) sampah di lingkungan juga merupakan salah satu bentuk pastisipasi masyarakat dalam pengelolaan sampah. Hal ini disebabkan karena ada beberapa daerah yang mungkin belum terjangkau oleh Pemerintah Daerah untuk dibangun Tempat Pembuangan Sementara (TPS) atau juga disebabkan terkendala berbagai persoalan lain seperti keterbatasan dana untuk pengadaan sarana Tempat Pembuangan Sementara (TPS) tersebut.

Pernyataan dari responden bahwa partisipasi masyarakat dengan membuang sampah di tempat yang telah ditentukan atau disediakan di Kecamatan Curup Tengah, Kabupaten Rejang Lebong secara umum sudah baik dengan rata-rata nilai atas jawaban responden adalah 3,91. Dimana masyarakat telah berpartisipasi aktif dengan selalu menyediakan bak atau wadah sampah di lingkungan tempat tinggal mereka sebagai sarana utama dalam membuang sampah yang dihasilkan sehari-hari untuk menjaga kebersihan lingkungan mereka.

Partisipasi Masyarakat dengan Tidak Membuang Sampah di Lapangan Terbuka atau Tempat Pembuangan
Tidak Resmi di Kecamatan Curup Tengah

Partisipasi masyarakat dengan tidak membuang sampah di lapangan terbuka atau tempat pembungan tidak resmi di Kecamatan Curup Tengah secara umum sudah baik. Hal ini dapat dilihat dari tidak adanya lahan atau lapangan terbuka yang dijadikan sebagai tempat membuang sampah di lingkungan sekitar. Selain itu kebiasaan membuang sampah dilapangan terbuka telah lama ditinggalkan masyarakat. Hal ini dikarenakan mereka telah mengerti, mempelajari dan merasa harus mengetahui dampak buruk membuang sampah yang tidak resmi bagi lingkungan sekitar. Demi menjaga kondisi lingkungan dari dampak kerusakan akibat membuang sampah di lapangan terbuka tersebut, masyarakat telah saling mengingatkan kepada sesama masyarakat agar tercipta rasa saling memiliki untuk menjaga lingkungan yang diikuti dengan rasa tanggung jawab untuk secara bersama-sama membersihkan beberapa lahan terbuka yang pernah dijadikan tempat membuang sampah masyarakat di lingkungan mereka.

Atas pernyataan-pernyataan responden yang disampaikan responden bahwa dampak yang dapat ditimbulkan dari membuang sampah di lahan terbuka atau tempat pembuangan sampah tidak resmi ini adalah berkembangnya beberapa bibit 
penyakit, menimbulkan bau yang tidak sedap bagi lingkungan sekitar, dan juga merusak pemandangan di lingkungan sekitar. Hal ini tentu saja berpengaruh terhadap kesehatan dan kesejahteraan masyarakat. Oleh karena itu, secara nyata diperlukan bentuk kerjasama dan pasrtisipasi masyarakat untuk mengatasi kebiasaan membuang sampah di lapangan terbuka karena membuang sampah di sembarang tempat seperti dilahan terbuka ini pada dasarnya bukan hal yang baru bahkan merupakan hal yang berlangsung sejak lama dan bahkan sudah menjadi budaya di kalangan masyarakat.

Menurut Mohammad Berkah (2011) sebenarnya permasalahan masyarakat yang membuang sampah sembarangan merupakan masalah budaya yang berlangsung selama bertahun-tahun dan memang perlu diubah sedari dini serta perlu pendidikan menyeluruh ke semua level masyarakat dan harus komprehensif penanganannya.

Dari dasar teori diatas diketahui bahwa sangat penting merubah kebiasaan membuang sampah di sembarang tempat termasuk di lahan terbuka atau tidak resmi dari semua kalangan masyarakat yang ada. Hal ini menjadikan pendidikan dan pengetahuan masyarakat akan dampakdampak yang timbul serta tata cara penanganan permasalahan kebiasaan masyarakat dalam membuang sampah sangat diperlukan agar masyarakat lebih merasa memiliki kondisi lingkungan demi kesejahteraan mereka.

Menurut Sidik et al. (1985) penimbunan sampah yang sesuai dengan persyaratan teknis akan membuat stabilisasi lapisan tanah lebih cepat dicapai. Dasar dari pelaksanaannya adalah meratakan setiap lapisan sampah, memadatkan sampah dengan menggunakan compactor, dan menutupnya setiap hari dengan tanah yang juga dipadatkan. Akan tetapi penimbunan sampah yang dilakukan masyarakat pada lahan terbuka di lingkungan mereka kebanyakan tidak sesuai dengan persyaratan teknis dan terkesan sampahsampah tersebut hanya dibiarkan atau tidak dikelola lebih lanjut. Hal ini yang disebabkan karena kebanyakan masyarakat tidak memahami persyaratan teknis pengelolaan sampah mereka yang dibuang di lahan terbuka. Selain itu juga kebanyakan masyarakat memang tidak memiliki waktu untuk mengurusi hal tersebut, dan masyarakat masih mengganggap hal tersebut adalah bentuk tanggung jawab pemerintah jadi biar pemerintah yang mengurusinya.

Dalam Ketentuan UU No. 18 tahun 2008 diketahui bahwa sebagai bentuk partisipasi masyarakat dalam pengelolaan sampah, masyarakat dilarang untuk membuang sampah pada lahan terbuka. Dimana dalam ketentuan UU No. 18 
tahun 2011 ini juga terdapat sanksi-sanksi yang dapat dikenakan terhadap masyarakat yang masih membuang sampah di lahan atau lapangan terbuka. Hal ini berarti pemerintah telah berupaya untuk menghilangkan kebiasaan masyarakat membuang sampah di lingkungan terbuka dengan harapan pada akhirnya kebijakan tersebut berguna untuk meningkatkan kualitas kehidupan dan kesejahteraan masyarakat. Oleh karena itu partisipasi masyarakat secara bersamasama dapat membantu merubah kebiasaan masyarakat membuang sampah di lahan terbuka yaitu dengan saling mengingatkan warga masyarakat yang lainnya akan adanya sanksi yang tegas bila mereka membuang sampah di lahan terbuka, selanjutnya secara nyata memberikan contoh bentuk kepedulian terhadap lingkungan sekitar dengan mengajak warga masyarakat bersama-sama membersihkan lahan atau lapangan terbuka yang masih digunakan sebagai tempat membuang sampah.

Berdasarkan teori dan dibandingkan dengan hasil penelitian yang telah dilakukan, bahwa nilai rata-rata jawaban responden terhadap kuisioner dan hasil wawancara yang dilakukan penelitian selama penelitian berlangsung, pernyataan dari responden bahwa partisipasi masyarakat dengan tidak membuang sampah di lapangan terbuka atau tidak resmi di Kecamatan Curup Tengah, Kabupaten Rejang Lebong secara umum sudah baik dengan rata-rata nilai atas jawaban responden adalah 3,77. Dimana masyarakat telah berpartisipasi aktif dengan selalu mencari tahu, merasa perlu mempelajari dan berusaha mengurangi dampak buruk yang dapat ditimbulkan dari kebiasaan membuang sampah di lapangan terbuka atau tempat pembuangan sampah di lingkungan sekitar.

Partisipasi Masyarakat dengan Tidak Membakar Sampah yang Tidak Sesuai dengan Persyaratan Teknis Pengelolaan Sampah di Kecamatan Curup Tengah

Partisipasi masyarakat dengan tidak membakar sampah yang tidak sesuai dengan persyaratan teknis pengelolaan sampah di Kecamatan Curup Tengah secara umum sudah baik. Hal ini dapat dilihat dari kepedulian responden untuk mengetahui dampak dari membakar sampah yang tidak sesuai dengan teknis bagi lingkungan sekitar, sehingga masyarakat selalu berupaya membakar sampah sesuai dengan teknis pengelolaan sampah yang ditentukan. Selain itu dari pernyataan responden diketahui bahwa responden merasa perlu memiliki sarana dan prasarana membakar sampah sesuai dengan teknis pengelolaan sampah yang 
ditentukan. Sebagai bentuk partisipasi, masyarakat telah berupaya saling mengingatkan kepada sesama warga masyarakat yang lain untuk mengurangi kebiasaan membakar sampah yang tidak sesuai dengan teknis pengelolaan sampah yang ditentukan. Oleh karena itu, sangat diperlukan sosialisasi atau penyuluhan dari Pemerintah Daerah tentang petunjuk membakar sampah yang sesuai dengan teknis proses pengelolaan sampah agar masyarakat dapat mengetahui secara pasti tentang tata cara atau petunjuk membakar sampah yang baik dan sesuai dengan teknis pengelolaan sampah.

Pembakaran sampah seringkali terjadi pada sumber dan lokasi pengumpulan terutama bila terjadi penundaan proses pengangkutan sehingga menyebabkan kapasitas tempat terlampaui. Hal ini dapat menimbulkan dampak yang buruk bagi lingkungan karena asap yang timbul sangat potensial menimbulkan gangguan bagi lingkungan sekitarnya, selain itu pembakaran sampah juga dapat membuat pengrusakan lapisan ozon yang berbahaya bagi lingkungan dan pemanasan global. Pembakaran sampah yang tidak menggunakan teknologi tinggi juga dapat mengakibatkan pada pencemaran dioksin. Hal ini disebabkan oleh pembakaran yang tidak sempurna (400 - 600 celcius) yang menyebabkan terbentuknya senyawa dioksin. Senyawa ini dapat terbentuk pada pembakaran dengan temperatur yang rendah. Senyawa dioksin ini merupakan jenis gas yang sangat beracun yang dapat memicu pertumbuhan kanker dalam sel tubuh manusia.

Menurut Salvato (1982) salah satu kelebihan insenerator adalah dapat mencegah pencemaran udara dengan syarat incenerator harus beroperasi secara berkesinambungan selama enam atau tujuh hari dalam seminggu dengan kondisi temperatur yang dikontrol dengan baik dan adanya alat pengendali polusi udara hingga mencapai tingkat efisiensi, serta mencegah terjadinya pencemaran udara dan bau.

Berdasarkan teori dan dibandingkan dengan hasil penelitian yang telah dilakukan, bahwa nilai rata-rata jawaban responden terhadap kuisioner dan hasil wawancara yang dilakukan penelitian selama penelitian berlangsung, pernyataan dari responden bahwa partisipasi masyarakat dengan tidak membakar sampah yang tidak sesuai dengan teknis persyaratan pengelolaan sampah di Kecamatan Curup Tengah, Kabupaten Rejang Lebong secara umum sudah baik dengan rata-rata nilai atas jawaban responden adalah 3,69. Dimana masyarakat telah mengetahui bahwa kebiasaan membakar sampah yang tidak sesuai dengan persyaratan teknis akan berdampak pada perusakan lingkungan. 
Partisipasi Masyarakat dalam

Pengelolaan Sampah di Kecamatan Curup Tengah

Partisipasi masyarakat dalam penentuan kebijakan pemerintah tentang pengelolaan sampah menunjukkan bahwa masyarakat telah melaksanakan apa yang disampaikan dalam ketentuan Undang-undang Nomor 18 Tahun 20008 tentang pengelolaan sampah, dimana masyarakat selalu berperan aktif dalam penentuan kebijakan Pemerintah. Kebijakan dan pelaksanaan kebijakan tentang pengelolaan sampah dianggap penting dalam pengelolaan sampah di daerah-daerah termasuk juga di daerah penelitian.

Partisipasi masyarakat dengan membuang sampah di tempat yang telah menunjukkan bahwa masyarakat telah memiliki tingkat kesadaran akan pentingnya pengelolaan sampah di lingkungannya. Hal ini disebabkan masyarakat sudah menyadari akan arti penting kebersihan bagi kesehatan dan lingkungan. Berdasarkan hasil penelitian ini dapat dilihat bahwa masyarakat telah memiliki kedisplinan yang tinggi untuk selalu menggunakan bak atau wadah sampah sebagai sarana membuang sampah yang ada di lingkungannya. Sehingga menunjukkan bahwa kepedulian masyarakat untuk selalu menggunakan dan menyediakan sarana bak atau wadah sampah dianggap penting dalam pengelolaan sampah di daerah penelitian. Partisipasi masyarakat dengan tidak membuang sampah di lapangan terbuka atau di tempat pembuangan tidak resmi menunjukkan bagaimana masyarakat telah menghindari cara-cara praktis yang dapat merusak lingkungan dalam pengelolaan sampah sehari-harinya. Hal ini disebabkan karena dapat berdampak pada tingkat keindahan dan kenyaman masyarakat yang ada di sekitar lapangan terbuka yang dijadikan tempat pembuangan sampah tersebut. Sehingga menunjukkan bahwa kesadaran dan kepedulian masyarakat untuk tidak menggunakan lapangan terbuka sebagai sarana untuk membuang sampah sehari-hari dianggap penting bagi lingkungan sekitar.

Partisipasi masyarakat dengan tidak membakar sampah yang tidak sesuai dengan teknis pengelolaan sampah yang baik menunjukkan bagaimana masyarakat telah berupaya untuk menjaga kondisi lingkungan udara yang ada di sekitarnya. Hal ini disebabkan karena membakar sampah yang tidak sesuai dengan teknis pengelolaan sampah yang baik dapat berdampak pada tingkat pencemaran udara. Sehingga menunjukkan bahwa kesadaran dan kepedulian masyarakat untuk tidak membakar sampah yang tidak sesuai dengan teknis pengelolaan sampah 
dianggap penting bagi pengelolaan sampah.

Menurut Kholil (2003) partisipasi masyarakat sangat menentukan keberhasilan pengelolaan sampah secara terpadu. Hal ini menunjukkan bahwa diperlukan swadaya masyarakat agar masyarakat dapat mengelola sampah sendiri tanpa harus menunggu pemerintah karena persoalan sampah langsung berdampak pada kehidupan masyarakat. Sedangkan Menurut Sumarnonugroho (1987) faktor yang menunjang keberhasilan pengembangan swadaya masyarakat adalah kemampuan masyarakat mengenai masalah mereka, keinginan dan keikutsertaan masyarakat untuk mencari alternatif-alternatif pemecahan masalah, keterlibatan masyarakat dan penyebarluasan metodemetode swadaya-berswadaya. Oleh karena itu partisipasi masyarakat dengan mengatasi permasalahan sampah dengan kemampuan mereka sendiri sangat mendukung pengelolaan sampah.

Lebih lanjut pada pasal 28 UU Nomor 18 Tahun 2008 tentang Pengelolaan Sampah, partisipasi masyarakat dalam pengelolaan sampah dapat dilakukan melalui pemberian usul, pertimbangan, dan saran kepada Pemerintah, perumusan kebijakan pengelolaan sampah, serta pemberian saran dan pendapat dalam penyelesaian sengketa persampahan. Sedangkan bentuk/aspek lain peran serta masyarakat yaitu masyarakat mematuhi ketentuan pada Pasal 29 ayat 4 Undang-undang Nomor 18 Tahun 2008 dengan membuang sampah pada tempat yang telah ditentukan dan disediakan, melakukan penanganan sampah dengan tidak menggunakan pembuangan terbuka atau lahan terbuka sebagai tempat membuang sampah atau pemrosesan akhir, serta selalu membakar sampah yang sesuai dengan persyaratan teknis pengelolaan sampah. Hal ini sangat penting karena bila tidak dilaksanakan masyarakat dapat dikenakan sanksi pindana atau denda terhadap setiap pelanggaran tersebut.

Berdasarkan dasar teori dan dibandingkan dengan hasil dari penelitian yang telah dilakukan dapat diketahui bahwa Partisipasi masyarakat dalam penentuan kebijakan Pemerintah Daerah tentang Pengelolaan sampah, Partisipasi masyarakat dengan membuang sampah pada tempat yang telah ditentukan atau disediakan, Partisipasi masyarakat dengan tidak membuang sampah di lapangan terbuka, dan Partisipasi masyarakat dengan tidak membakar sampah yang tidak sesuai dengan persyaratan teknis pengelolaan sampah di Kecamatan Curup dalam pengelolaan sampah di Kecamatan Curup Tengah sudah baik. Hal ini menunjukkan bahwa secara umum Partisipasi masyarakat Dalam Pengelolaan 
Sampah di Kecamatan Curup Tengah juga sudah baik dengan nilai rata-rata jawaban responden terhadap ke empat bentuk partisipasi masyarakat dalam penelitian adalah 3,8. Sehingga jelas diketahui, baik secara individu maupun bersama-sama masyarakat di Kecamatan Curup Tengah telah memiliki kesadaran yang baik untuk mendukung semua program dan ketentuan dalam pengelolaan sampah yang dilaksanakan di daerahnya.

\section{Implikasi Penelitian}

Berdasarkan hasil analisis data, maka dapat dikemukakan implikasi penelitian yang merupakan suatu langkah perbaikan berkesinambungan terhadap partisipasi masyarakat dalam pengelolaan sampah yang ada di Kecamatan Curup Tengah, Kabupaten Rejang Lebong, Bengkulu. Adapun langkah-langkah yang dapat dilakukan adalah sebagai berikut :

1) Pemerintah Daerah secara berkesinambungan melakukan sosialisasi atau penyuluhan untuk menyuarakan program pengelolaan sampah rumah tangga, sehingga dapat menyerap aspirasi masyarakat agar kebijakan pengelolaan sampah yang dihasilkan oleh Pemerintah Daerah benar-benar dapat mensejahterakan masyarakat.

2) Meningkatkan pemahaman, kesadaran dan peran serta masyarakat secara insentif melalui penyuluhan, pendidikan serta melalui media cetak dan elektronik.

3) Meningkatkan dan mengupayakan terbentukanya pola jaringan yang peduli terhadap permasalahan lingkungan hidup khusunya permsalahan pengelolaan sampah.

4) Menyiapkan fasilitas pembuangan sampah baik itu bak sampah maupun sarana pembuangan sampah sementara seperti gerobak sampah. Gerobak sampah dinilai cukup efektif untuk melayani wilayah pemukiman yang tidak dapat dilalui dengan truk pengangkut sampah. Dalam mengefektifkan penggunaannya, maka gerobakgerobak sampah tersebut diserahkan kepada pihak kelurahan-kelurahan yang ada di wilayah Kecamatan Curup Tengah.

5) Dalam menanggulangi jumlah sampah yang makin meningkat sejalan dengan perluasan kota, peningkatan jumlah penduduk dan peningkatan taraf hidup masyarakat di masa yang akan datang, Pemerintah Daerah hendaknya terus meningkatkan jumlah dan alat pengangkutan sampah. Demikian juga personil yang menangani urusan kebersihan kota utamanya tenaga lapangan serta sistem 
pengelolaan yang harus dilakukan secara terencana dan terpadu.

6) Dalam menghindari pembakaran sampah yang menimbulkan polusi berupa timbulnya asap dan bau asap yang kurang sedap serta kemungkinan terjadinya bahaya kebakaran terutama pada pemukiman padat, sangat diharapkan bentuk kerjasama masyarakat dan Pemerintah Daerah dalam mengelola sampah. Salah satu cara yang dapat ditempuh adalah dengan menyediakan sarana dan prasarana seperti insenerator di wilayah Kabupaten Rejang Lebong.

7) Pemerintah memberikan bantuan fasilitas termasuk biaya untuk pengelola karena biaya pengelolaan sampah merupakan kewajiban pemerintah (amanat UndangUndang RI No 18 tahun 2008).

\section{SIMPULAN}

Berdasarkan pengamatan, kusioner yang dibagikan dan pelaksanaan wawancara oleh penulis dapat ditarik beberapa kesimpulan sebagai berikut :

1. Partisipasi masyarakat dalam penentuan kebijakan oleh Pemerintah Daerah tentang pengelolaan sampah di Kecamatan Curup tengah, Kabupaten Rejang Lebong, Bengkulu sudah baik, dimana masyarakat selalu berupaya memberikan saran, usulan dan pendapat dalam penentuan kebijakan Pemerintah Daerah tentang pengelolaan sampah.

2. Partisipasi masyarakat dalam membuang sampah di tempat yang telah ditentukan atau disediakan di Kecamatan Curup tengah, Kabupaten Rejang Lebong, Bengkulu sudah baik, dimana masyarakat selalu menyediakan bak atau wadah di sekitar rumah atau tempat tinggal untuk membuang sampah.

3. Partisipasi masyarakat dengan tidak membuang sampah di lahan terbuka atau tempat pembuangan tidak resmi di Kecamatan Curup tengah, Kabupaten Rejang Lebong, Bengkulu sudah baik, dimana masyarakat telah, merasa harus dan selalu berupaya untuk mencari tahu bahwa membuang sampah di lahan terbuka atau tempat tidak resmi dapat memberikan dampak yang buruk bagi lingkungan, sehingga selalu membersihkan lahan terbuka yang dijadikan tempat membuang sampah.

4. Partisipasi masyarakat dengan tidak membakar sampah yang tidak sesuai dengan persyaratan teknis pengelolaan sampah di Kecamatan Curup tengah, Kabupaten Rejang Lebong, Bengkulu sudah baik dimana masyarakat telah, merasa harus dan selalu berupaya 
untuk mencari tahu bahwa membakar sampah yang tidak sesuai dengan persyaratan teknis akan berdampak pada perusakan lingkungan, sehingga dapat mencegah tindakan membakar sampah yang tidak sesuai dengan teknis pengelolaan sampah yang baik.

5. Secara umum partisipasi masyarakat di Kecamatan Curup tengah, Kabupaten Rejang Lebong, Bengkulu dalam bidang pengelolaan sampah sudah baik dimana masyarakat selalu berpartisipasi dalam membuang sampah pada tempat yang telah ditentukan atau disediakan.

\section{DAFTAR PUSTAKA}

Andang Binawan. 2010. Peduli Sampah Peduli Selangkah. http://ratnaariani.wordpress.com /2008/06/02/peduli-sampah-peduliselangkah-al-andang-l-binawan-sj (7 Juni 2011).

Badan Pertanahan Nasional Kabupaten Rejang Lebong, 2009

Badan Pusat Statistik Kabupaten Rejang Lebong. Kabupaten Rejang Lebong Dalam Angka 2010. BPS. Rejang Lebong.

Badan Pusat Statistik Kabupaten Rejang Lebong. Curup Tengah Dalam Angka 2010. BPS. Rejang Lebong.

Badan Standarisasi Nasional (BSN). 2002. Standar Nasional Indonesia (SNI) 19-2454-2002 tentang Tata Cara Teknik Operasional Pengelolaan Sampah Perkotaan. Departemen Pekerjaan Umum. Jakarta

Basrowi dan Suwandi. 2008. Memahami Penelitian Kualitatif. Rineka Cipta. Jakarta.
Departemen Pekerjaan Umum. 2006. Permen PU Nomor : 21/PRT/M/2006 tentang Kebijakan Dan Strategi Nasional Pengembangan Sistem Pengelolaan Persampahan (KSNP-SPP). Jakarta.

Hartoyo. 1998. Pemanfaatan Pengelolaan Sampah Kota Jawa Timur, Bahan Seminar Nasional Penanganan Sampah Kota, Tesis. Fakultas Teknik Brawijaya. Malang.

Indra Yones, 1997. Kajian Pengelolaan Sampah Di Kota Ranau IBu Kota Kabupaten Natuna Propinsi Kepulauan Riau. Tesis. Magister Ilmu Lingkungan. UNDIP. Semarang

Kodoatie, Robert J. 2003. Manajemen Dan Rekayasa Infrastruktur. Pustaka Pelajar. Yogyakarta.

Kantor Kecamatan Curup Tengah, Data Kependudukan Kecamatan Curup Tengah, 2010.

Kuncoro, S. 2009. Pengelolaan Sampah Terpadu Dengan Sistem Node, Sub Point, Center Point. Kanisius. Yogyakarta.

KR. 2000. Kedaulatan Rakyat. Yogyakarta.

La Ode Luali. 2006. Pengaruh Faktor Sosial Ekonomi Terhadap Persepsi, Sikap, Dan Partisipasi Masyarakat Dalam Pengelolaan Sampah, Studi Kasus Kota Raha Kabupaten Muna Provinsi Sulawesi Tenggara. Tesis. Magister Ilmu Lingkungan. UGM. Yogyakarta.

Maxpell Technology. 2011. Proposal Penawaran Incenerator Pembakaran Sampah. Hal.3-4. Bandung.

Meykowati Isa. 2010. Sistem Pengelolaan Sampah di Kota Tilamuta Kabupaten Boalemo Provinsi Gorontalo. Tesis. Magister Teknik Pembangunan Wilayah Dan Kota. UNDIP. Semarang.

Mohammad Berkah. 2009. Giatkan Buang Sampah Pada Tempatnya. http://www.greenradio.fm/news/late 
st/263-giatkan-buang-sampah-padatempatnya (7 Juni 2011)

Mubyarto. 1984. Strategi Pembangunan Pedesaan Pusat Penelitian. Pusat Penelitian Pembangunan Pedesaan Dan Kawasan UGM. Yogyakarta.

Murthado. 1987. Penanganan Dan Pemanfaatan Limbah Padat. Madya Tama Sarana Perkasa. Jakarta.

Nazir, M. 1988. Metode Penelitian. Penerbit Graha Indonesia. Jakarta.

Nonon. S \& Sigit. P. 2008. Strategi Dan Mekanisme Perencanaan Sosial Partisipatif Dalam Pengelolaan Sampah Permukiman Berbasis Masyarakat Di DKI Jakarta. Jurnal Politik Volume 4/No.2:338

Republik Indonesia. 2008. UndangUndang No. 18 Tahun 2008 tentang Pengelolaan Sampah. Lembaran Negara RI Tahun 2008, No. 69. Sekretariat Negara. Jakarta.

Saifuddin, A. 1988. Sikap Manusia, Teori dan Pengukurannya. Pustaka Pelajar. Yogyakarta.

Slamet, S.J. 2000. Kesehatan Lingkungan. Gadjah Mada University Press. Yogyakarta.

Soekidjo Notoatmodjo.2003. Prinsipprinsip Dasar Ilmu Kesehatan Masyarakat. Cet. Ke 2. Rineka Cipta. Jakarta.
Sugiarto, et, Al. 2001. Teknik Sampling. Gramedia Pustaka Utama. Jakarta.

Sukanto, R dan Brodjonegoro. 1989. Ekonomi Lingkungan, Suatu Pengantar. BPFE. Yogyakarta.

Stasiun Geofisika Kepahiang Bengkulu, 2010.

Taylor, J.L \& Williams, D, G. 1982. Urban Planning Practices In Developing Countries. Pergamon Press. Oxford.

Tchobanoglous, Theisen, and Vigil. 1993. Intergrated Solid Waste : Enggineering Principle and Management Issues. McGraw-Hill, Inc.

Thorikul Huda.2009. Dioksin Senyawa B3 Penyebab Kanker. http://thorik.staff.uii.ac.id/2009 /08/23/dioksin-senyawa-b3penyebab-kanker/. (7 Juni 2011).

Tjokroamidjoyo, B. 1987. Pengantar Administrasi Pembangunan. LP3ES. Jakarta

Unlastnoel. 2009. Dampak Lingkungan Yang Ditimbulkan Akibat masalah Sampah.

http://unlastnoel.wordpress.com/200 9/09/12/dampak-lingkungan-yangditimbulkan-akibat-masalahsampah/. (7 Juni 2009). 